\title{
SRI LANKA'S FIRST DECADE OF INDEPENDENCE: PHASE II IN THE TRANSFER OF POWER
}

\author{
By K. M. de Silva
}

To the student of politics few former British Colonies in Asia and Africa afford a more worthwhile field for investigating the complexities of the transfer of power than Sri Lanka. And yet the Sri Lankan experience is quite exceptional for two reasons. Not merely was the process of transfer of power from British hands peaceful in striking contrast to that in the Indian subcontinent and Burma, but more importantly she provides a unique example of power being transferred through the electoral process, and completely democratically and constitutionally, from the original legatee of the British to a successor. This present essay seeks to delineate some of the crucially important features in the political processes involved in this second phase of the transfer of power.

\section{The constitutional structure ${ }^{1}$}

We need to begin our survey with a brief look at the constitution - the Soulbury Constitution - under which Sri Lanka achieved independence in 1948. Perhaps the most striking feature of this constitution is that it followed the Westminster prototype more closely than most other Commonwealth constitutions. This is not surprising in view of the fact that it was of British origin in contrast to the autochthonous constitution drafted for India by her Constituent Assembly. But it is important to remember that the Soulbury Constitution followed in its basic structure and much of its details the pattern set out in the constitutional framework drafted for D.S. Senanayake in 1944 - and subsequently, overwhelmingly approved by the State Council ${ }^{2}$ - modified to suit the changed circumstances of 1947-48. And these modifications were few and not very substantial.

The draft scheme of 1944 provided for a Cabinet form of government adhering to the principles of collective responsibility, a unicameral legislature, and a GovernorGeneral as head of state ${ }^{3}$. The question of a second chamber was left for the future legislature to decide, by a simple majority, if they wanted one. The Soulbury Constitution took over the scheme but added a second chamber $\perp$ the Senate. The draft constitution incorporated a scheme of representation which, without compromising the territorial principle as against the communal, gave weightage to minority groups and to backward and sparsely populated areas. This scheme was adopted in its entirety by the Soulbury Commission (and has survived the supercession of this latter constitution in 1972). The Soulbury Constitution was a unitary one, "almost completely flexible", and the courts - as in other Dominion constitutions - could review the constitutionality of legislation and the legitimacy of the use of power.

1 For an authoritative discussion of Sri Lanka's constitution since independence see, A. J. Wilson, Politics in Sri Lanka, 1947-1973 (London, 1974), Chapter VI, pp. 189-265. See also, Sir Ivor Jennings, The Constitution of Ceylon, 3 rd ed. (O.U.P., Bombay, 1953).

2 This was the island's legislature under the Donoughmore Constitution (1931-1947).

3 See Sessional Paper XIV of 1944 (Colombo, 1944), The Reform of the Constitution. 
On the initiative of D.S. Senanayake the draft constitution of 1944 contained clauses which prohibited the legislature from introducing laws which discriminated against minorities. This was done as a gesture of generosity and reassurance to the minorities. These clauses were incorporated in the Soulbury Constitution [s. 29(2)], as the only serious limitation on the sovereignty of the new Parliament. In retrospect it would seem that the rights of minorities did not receive adequate protection in the Soulbury Constitution but at the time of the transfer of power the constitutional guarantees against discriminatory legislation seemed sufficiently reassuring to the minorities largely because of the trust and confidence they reposed in D.S. Senanayake. The Soulbury Constitution unlike India's new constitution lacked a Bill of Rights.

The link with the British crown was maintained in strict law even though it had no practical significance in the lives of the people or in the affairs of the country. But the existence of this link tended to obscure the fact of the island's independence from subjection to Britain. Besides, this link, in contrast to the situation in most white Dominions, was without meaning for an Asian people.

\section{S. Senanayake and the transfer of power ${ }^{4}$}

The final phase in the transfer of power had begun under the leadership of D.S. Senanayake. There were two noteworthy points of interest in his negotiations with Britain on this issue. Firstly, he was guided by a strong belief in ordered constitutional evolution to Dominion Status on the analogy of constitutional development in the white Dominions. In insisting that Dominion Status should remain the prime object of policy, and that this should be attained in association with rather than in opposition to the British, he placed himself in direct opposition to the views adopted by the Ceylon National Congress in 1942 (in response to the younger policy makers who were becoming increasingly influential within it) that independence ${ }^{5}$ rather than Dominion Status should be the goal of Sri Lanka's development. Secondly he feared that with the British withdrawal the British Empire in Asia in the familiar form in which it had existed would have ended, and that the political prospects in Asia would be hardly encouraging. A profound suspicion of India was the dominant strand in his external policy. Accordingly it was as a policy of re-insurance for the country during the early years of independence when it was not impossible that there might be a political vacuum in South Asia that he viewed the agreements on Defence and External Affairs negotiated by Whitehall as a prelude to the grant of Dominion Status to Sri Lanka ${ }^{6}$.

It was in his internal policy that he left the impress of his dominant personality and his moderate views. The guiding principles were: his conception of Sri Lanka

\footnotetext{
4 For discussion of these problems see the author's chapter "The History and Politics of the Transfer of Power' in K. M. de Silva (ed), The University of Ceylon, History of Ceylon Vol. III (Colombo, 1973), pp. 489-533; see also his chapter "The Transfer of Power in Sri Lanka - A Review of British Perspectives" in KM. de Silva et al (eds). Sri Lanka Since Independence, special issue of The Ceylon Journal of Historical and Social Studies n. s. Vol. IV (forthcoming).

5 Independence did not carry the lingering connotation of constitutional subordination to Britain which Dominion Status, at this time, appeared to have. India's acceptance of membership of the Commonwealth went a long way to demonstrating that Dominion Status was in fact complete independence with the advantages of membership of a world-wide Commonwealth.

6 The agreements on Defence and External Affairs are reviewed in A. J. Wilson, op. cit., pp. 275-77.

6 The agreements on Defence and External Affairs are reviewed in A. J. Wilson, op, cit., pp. 275-77;
and Lucy M. Jacob, Sri Lanka, From Dominion to Republic (New Delhi, 1973), pp. 21-63, and pp. 195-99.
} 
as a multi-racial democracy, and a multi-racial national state with an all-island focus, without any special, much less, exclusive association with any ethnic group, or any section of an ethnic group; and his commitment to the maintenance of the Liberal ideal of a secular state in which the lines between state power and religion were scrupulously demarcated. Here again he placed himself in opposition to an increasingly influential current of opinion which viewed the Sri Lanka polity as being essentially Sinhalese and Buddhist in character, and which urged that government policies should be fashioned to accommodate a far-reaching transformation of the island's politics to build a new Sri Lanka on traditional, ideal, SinhalaBuddhist lines. Implicit in this was a rejection of the concept of a multi-racial politiy, as well as the concept of a secular state. In his emphasis on a secular state there was much more in common between D. S. Senanayake and his Marxist critics, than between him and S.W.R.D. Bandaranaike and his adherents within the new government.

D.S. Senanayake, in contrast, was sensitive to minority anxieties. To a much greater extent than the bulk of his colleagues and associates in the national leadership he understood the implications of the fact that Sri Lanka was a plural society and his policies for the transfer of power and in the early years of independence were framed on that realistic basis. Firstly, there were the guarantees against legislation discriminating against minorities embodied in the Soulbury Constitution. As we have seen these guarantees had been borrowed from provisions in the Minister's Draft Constitution of 1944 which had been formulated at D.S. Senanayake's insistence. Secondly, there was the initiative he took in forming the United National Party (UNP). This was designed to make a fresh start in politics in the direction of a consensus of moderate opinion in national politics; it was to be a political party necessarily representative of the majority community, but at the same time acceptable to the minorities. His own standing in the country was sufficient guarantee of its being acceptable to the majority, but there is no doubt that its position among the Sinhalese was strengthened by S.W.R.D. Bandaranaike's decision to bring in his Sinhala Maha Sabha. From the beginning it had the enthusiastic approval of the small but influential Christian minority, and the Muslims who had in the past given substantial support to the Tamils in their political campaigns at last broke away and sought association with the new party. When the Tamil Congress crossed over to the new government in 1948 the equilibrium of political forces which D.S. Senanayake had sought to establish was stabilised at a level which he found acceptable, even though the Tamil Congress did not lose its separate identity and despite the fact that a section broke away from it into a stubborn but, at that time, seemingly futile opposition. Indeed the entry of the Tamil Congress into the new government helped convert it into very much a consensus of moderate political oponion in the country. Only the Indian community, consisting in the main of plantation workers, were left out. But there were special reasons for that, for they were regarded as an unassimilated group without roots in the country. The decision to leave them out was deliberately taken on that account. To the extent that he shared the attitudes and prejudices of the great majority of Sinhalese politicians with regard to the Indian question the status of Indian plantation workers in the Sri Lanka polity, - his conception of a multi-racial political structure was flawed.

Thirdly, D.S. Senanayake thwarted all efforts to abandon the concept of a secular state, and the principle of the religious neutrality of the state. He succeeded in this 
to the extent that in 1948 , despite some Buddhist displeasure over the continued prestigious and influential position enjoyed by the Christians, there seemed little or no evidence of the religious turmoil and linguistic conflicts that were to burst to the surface in 1955-56.

If the political leadership in Sri Lanka took pride in the fact that the transfer of power was smooth, they seemed oblivious to the political perils involved in making the process so bland as to be virtually imperceptible to those not directly involved. The last British governor of the island became its first Governor-General after independence. Next there was the notable difference between the constitutional and legal instruments which conferred independence on Sri Lanka, and the cognate process in other parts of South Asia - for India and Pakistan, Acts of Parliament; for Burma, a specially negotiated treaty; while for Sri Lanka a mere Order-inCouncil. All this seemed to suggest a qualitative difference in the nature of the independence that was being achieved when no meaningful difference in status was either intended by Britain or accepted by Sri Lanka's leaders in the Board of Ministers prior to independence, and later, in the Cabinet.

Moreover the Soulbury Constitution came under attack from its inception? ${ }^{7}$. Leftwing critics of D.S. Senanayake's government were able to argue that the independence achieved in 1947-48 was spurious. And the gibe of a "fake" independence which they kept hurling at the government evoked a positive response from a wider circle of the political nation in the new Dominion than merely the left-wing alone. This was because the Indian experience seemed to provide a more emotionally satisfying example than the process by which power was transferred in Sri Lanka - independence granted from above (as in Sri Lanka) was regarded as being much less satisfying to the spirit of nationalism than if it had been won after prolonged strife and untiring sacrifice. Above all the Agreements on Defence and External Affairs negotiated prior to the transfer of power helped to give an air of credibility to the argument that the independence confered on Sri Lanka was flawed. The Agreements themselves were regarded as badges of inferiority, and checks on full sovereignty in external affairs; moreover fears were expressed about secret clauses not divulged or a secret treaty even more detrimental to the island's status as an independent nation. Events were to prove that these fears and suspicions were without foundation in fact, and certainly no secret undertaking had been given by Sri Lanka in 1947-48, but until 1956-57 suspicion on this score persisted.

\section{The successor regime consolidates its position}

It was from the left that the threat to the new government and the balance of forces it sought to establish was expected. At the general elections of 1947 the left-wing parties reaped the electoral rewards that were available to any credible opponents of the newly formed UNP most of whose leadership had enjoyed a substantial measure of political power since the 1930's. Never again were the Trotskyists and the Communists so well represented in Parliament as they were after the general election of 1947 when they and their fellowtravellers held about a fifth of the membership. Indeed in the heady aftermath of the

7 Marxist groups in Parliament advocated the establishment of a Constituent Assembly to draft an autochthonous constitution for the island. 
elections there were sanguine expectations in some quarters of the possibility (admittedly somewhat remote) of the left-wing forming the nucleus of an alternative government to one dominated by the UNP. D.S. Senanayake paid exaggerated attention to the presumed threat from the left, and took extraordinary steps to meet it.

Fristly, as regards the demarcation of constituencies to the new Parliament, the voting strength in them varied from province to province, and sometimes within provinces to the point where the resulting distortions appeared to vitiate the principle of one man one vote. While this electoral demarcation was primarily designed to provide weightage in representation to the backward and sparsely populated areas in some of which the minority groups - Tamils and Muslims - lived, the electoral balance was heavily in favour of the rural areas which generally were more conservative in outlook. Secondly, the Citizenship Act of 1948, the Indian and Pakistani Residents (Citizenship) Act of 1949 and the Parliamentary Elections (Amendment) Act of 1949 deprived the bulk of the Indian Tamils resident in Sri Lanka of their citizenship rights and franchise. Sinhalese opinion, especially in the Kandyan areas was deeply suspicious of the Indian Tamils, and apprehensive of the prospect of Indian domination of the central highlands of the island. These fears were aggravated by the fact that the indigenous Tamils were not disinclined to regard the Indians as an additional source of political strength. More importantly the left-wing groups began to look upon the Indian workers as a potentially powerful component of their trade union movement if they could be weaned away from the Ceylon Indian Congress which controlled them. In the general elections of 1947 the Indian vote was decidedly anti-UNP and where there were no candidates of the Ceylon Indian Congress the Indians had voted enthusiastically for the left-wing parties and left independents. And within the new Parliament representatives of the Ceylon Indian Congress sat on the opposition benches and gave their support to the "left". Thus the new citizenship legislation not only served to assuage the fears and suspicions of the Sinhalese in general and the Kandyans in particular, but also to demolish a potentially powerful prop of the left-wing groups. The immediate effect of this was to distort the electoral balance even more markedly than before and to make the Sinhalese rural voter the arbiter of the country's politics. With each fresh delimitation of constituencies thereafter his positions has been strengthened. This new electoral balance gave the UNP and its allies a decisive advantage in the general elections of 1952, and the left-wing parties were greatly handicapped. Thirdly, the Public Security Act of 1947, and the Trade Union (Amendment) Act of 1948 were directed against the Marxist dominated working class organisations and were the direct result of the working class agitation and industrial turmoil of $1945-47$.

Within a year of the grant of independence in 1948 the UNP had stabilised its position. Its parliamentary position improved quite substantially with the entry of G.D. Ponnambalam and the bulk of the Tamil Congress members into the government. Not only were the ranks of the opposition depleted but the government was also able to require the formidable oratorical and forensic skills of the Tamil Congress leader. And in the country at large there was the impression that an intractable political problem - that of the indigenous Tamils - was being solved on the basis of reconciliation and compromise. 
In contrast the left-wing parties were as divided - by personality conflicts and ideological disputes - in 1950 as they had been in 1947 at the time of the elections. For almost three years they could not agree among themselves on a leader of the opposition. The LSSP, the largest Marxist group, were in favour of its leader accepting this position, but the more doctrinaire Trotskyist group, the Bolshevik Samasamaja Party, were hostile to the suggestion, and so for that matter were the Communists. It was in June 1950, after the two Trotskyist groups had merged that the LSSP leader took office as Leader of the opposition. The Communists gave him no support in this enterprise.

Yet despite all this the political settlement established by D.S. Senanayake was less stable than it appeared to be. The forces that sought to upset it were as insidious as they were truly formidable. And to grasp the significance of these we need to turn to the nature of nationalism in Sri Lanka. There was always a tendency on the part of the Sinhalese to equate their own ethnic nationalism with a wider allisland one, to assume that these - Sinhalese nationalism and Sri Lanka nationalism - were one and the same. In support of this they advanced arguments based on history and immemorial tradition. But this was a short-sighted and unrealistic attitude. The Tamils, the most numerous and articulate group among the minorities, passionately rejected this identification of the sectional interests of the majority with the wider all-island focus of Sri Lanka nationalism. The Christians (among the Sinhalese and Tamils) and more particularly the Roman Catholics were equally apprehensive and resentful of the common tendency to equate Sinhalese nationalism with Buddhism. The Tamils for their part, developed an inward-looking ethnic nationalism of their own, though this, like its Sinhalese counterpart, lacked cohesiveness and even a touch of authenticity till language became, after independence, the basis of these rival nationalisms.

The other version of nationalisms, a Ceylon or Sri Lanka nationalism emphasised the common interests of the island's various ethnic and religious groups. It had as its basis an acceptance of the reality of a plural society, and sought the reconciliation of the legitimate interests of the majority and minorities within the context of an all-island polity. Its most influential advocate at the time of the transfer of power was D.S. Senanayake.

In 1948 , this latter version of nationalism seemed to be a viable alternative to the narrower sectionalisms described above, and held out the prospect of peace and stability in the vital first phase of independence. It was based on a double compromise: the softening of Sinhalese dominance by the establishment of an equilibrium of political forces whose keynote was moderation, and an emphasis on secularism, a refusal to mix state power and politics with religion, even though the concept of a special responsibility for Buddhism was tacitly accepted.

This Sri Lanka or Ceylonese nationalism had a crucial flaw. It was basically elitist in conception, and it did not have any popular support which extended beyond the political establishment. It required D.S. Senanayake's enormous personal prestige, and consummate statecraft to make it viable.

The immediate effect of D.S. Senanayake's death in March 1952 was to give it another lease of life. The massive electoral victory which his son and successor won in 1952 was in many ways a ringing endorsement given by the electorate to the life's work of D.S. Senanayake. The election itself had taken place in an atmosphere of emotionalism following upon the death of the elder Senanayake. The 
equilibrium of forces he had established was seemingly stabilised by the formidable support received by his successor.

And yet the first major challenge to this system had appeared when S.W.R.D. Bandaranaike crossed over to the opposition in July 1951 with a small group of his supporters. In September 1951 the Sri Lanka Freedom Party was inaugurated as a centrist political force which deliberately sought to become the focal point of all interest groups dissatisfied with the UNP which were, at the same time, opposed to Marxist solutions to the country's problems. The nucleus of a democratic alternative to the UNP had emerged.

Its populist programme was directed at the large protest vote that went to the Marxist parties for want of an alternative, and to the rural areas which formed the basis of the UNP's hold on political power in the country. The Marxist left had failed to make much of an impact on the rural areas, and their perennial ideological disputes, their shifts and rifts and re-alignments, incomprehensible to the bulk of the electorate, carried no meaning to all save the true believers. More importantly the left was just as unsympathetic as the UNP leadership to the aspirations of the Buddhist activists with regard to religion, language and culture, and it was to this group with its deep sense of grievance, its social and economic discontent, and its resentment at the neglect by both the UNP and its left-wing critics, that the SLFP turned.

The prospect of a classic confrontation between D.S. Senanayake and S.W.R.D. Bandaranaike as the advocates of two diametrically opposed versions of nationalism vanished with the death of the former on 22 March 1952. The electorate rejected Bandaranaike's party in 1952. But significantly the SLFP emerged from the election as a redible democratic alternative to the UNP and its leader took on the role of the Leader of the opposition on the traditional Westminster style.

\section{The strands of continuity}

The tide turned in Bandaranaike's favour within three years of his setback at the polls in 1952. The background to his victory at the general elections of 1956 has been surveyed in a number of books and monographs ${ }^{8}$. Suffice it to say for the purposes of this essay that it marked a watershed in Sri Lanka's history in the rejection of so much that had come to be accepted as part of the normal order of things in post-colonial Sri Lanka. But the strands of continuity are just as significant as the elements of farreaching change. The continuity is seen in three important features: parliamentary democracy; the Commonwealth connection; and the survival of the Soulbury Constitution.

Of these, the first two reflected Bandaranaike's own personal political attitudes and inclinations more than the forces he gave leadership to. He was a liberal democrat and a firm believer in parliamentary government. He sought power through the electoral process and by his success demonstrated its value as an instrument of political change in a post-colonial situation. It was a lesson which the Sri Lanka electorate has absorbed with alacrity and increasing conviction. As for the Commonwealth connection, the fact that Nehru's India had

\footnotetext{
8 The outstanding work on this theme is Howard Wriggins, Ceylon. The Dilemmas of a New Nation
} (Princeton University Press, 1960). 
voluntarily opted for membership had long since removed any lingering suspicions about limitations on sovereignty in Dominion Status and Bandaranaike saw no reason to terminate Sri Lanka's association with the Commonwealth.

The survival of the Soulbury Constitution after 1956 was, however, less a matter of conviction than convenience. During the period of UNP rule there were no moves to amend the constitution in any significant way much less to replace it with another. The elections of 1952 had given the UNP an effective two-thirds majority which might have been used for such purposes if it had been so minded; but it was not though there were occasional murmurs about republican status for Sri Lanka. The left-wing both within and outside Parliament persisted in its opposition to the constitution but its power base was not strong enough or wide enough to make this opposition anything more than symbolic or ritualistic. The emergence of the Sri Lanka Freedom Party in 1951 did not, initially, strengthen the forces of constitutional reform for the new party did not have the same dogmatic opposition to the Soulbury Constitution as the left-wing groups. Indeed S.W.R.D. Bandaranaike had been a member of the Board of Ministers and the Cabinet at the time the constitution was negotiated and accepted. He had seconded D.S. Senanayake's forma motion introduced in the State Council on 8 November, 1945, accepting the Soulbury Constitution.

Bandaranaike's main concern at the time he became Prime Minister in 1956 was about limitations and curbs on Sri Lanka's sovereignty, and he was anxious to eliminate these. But he was thinking more about the Defence Agreements with Britain signed at the time of the transfer of power and less about the Soulbury Constitution itself. Very soon he was able to satisfy himself that these Agreements were not detrimental to the country's status as a free and sovereign state. (And it is significant that these Agreements, for all the criticisms they have been subjected to from time to time, have never yet been abrogated.) At the Commonwealth Prime Ministers Conference in 1956 Bandaranaike secured the agreement of his fellow Prime Ministers for his country's transition to republican status within the Commonwealth. He was anxious, at the same time, to introduce amendments to the Soulbury Constitution. On his initiative a Joint Parliamentary Select Committee on Constitutional Reform was set up on 2 November 1957 to prepare the basis of a new constitutional structure. But the political instability of the last phase of his tenure of office as Prime Minister put paid to any prospects of introducing amendments to the constitution ${ }^{9}$.

The survival of the Soulbury Constitution, without fundamental change, during this decade can be explained on a different basis as well. The comparative flexibility of the constitution, and the lack of a bill of fundamental rights enabled the political structure to accommodate itself to a series of far-reaching changes most if not all of which adversely affected ethnic and religious minorities. As early as 1948 the Ceylon Citizenship Act eliminated the vast bulk of the Indian plantation workers from the electoral registers by the simple device of defining the right to citizenship far more rigidly than under the Donoughmore Constitution. It was thus demonstrated that the constitutional obstacle of Section 29[2][b] would not operate as long as legislation was so framed that there might be a restriction in fact but not in legal form, and the restriction was made applicable to all sections of the community and not to a specific group. When S.W.R.D.

\footnotetext{
9 The only amendment secured was with regard to the law for the delimitation of constituencies. This amendment was introduced in 1959.
} 
Bandaranaike's Official Language Act was introduced in the House of Representatives in 1956, the Speaker ruled that it was not a constitutional amendment and therefore required only a simple majority. (In 1960 the Roman Catholics found to their dismay that the constitution provided no protection for them in their campaign to preserve the status-quo in education.)

Equally important nationalisation of local and foreign business ventures was facilitated by the fact that there was no provision in the constitution for just and expeditious payment of compensation. Thus there was no constitutional protection for special economic interests and property rights in general.

\section{Linguistic nationalism and its implications}

These elements of continuity were clearly overshadowed by Bandaranaike's purposeful demolition of the balance of political forces which D.S. Senanayake had endeavoured to establish and sustain as the basis of the post-colonial Sri Lanka polity. What this amounted to was a rejection of the concept of a Sri Lanka nationalism which D.S. Senanayake had striven to nurture, and to substitute for it a more democratic and populist form of nationalism which was, at the same time, fundamentally divisive in its impact on the country.

By the mid 1950's the UNP government's position in the country was being undermined even though its hold on Parliament appeared to be as strong as it ever was. Religion, language and culture were emerging as the central issues of the day, and with regard to these the UNP was patently unsympathetic and lacking in understanding.

The Sinhala educated intelligentsia found that rewarding careers were closed to them by the pervasive dominance of English as the language of administration. Though they were not without influence in the villages, they had seldom, in the past, been able to exert any influence on a national scale and they felt that they had been unjustly excluded by the western educated elite from a share of power commensurate with their numbers. More importantly they felt that they were better able than the latter to speak for the villagers. By extension they also felt that the Tamil community had taken an unfair share of power by virtue of their superior educational opportunities.

In addition they felt that in its spiritual home Theravada Buddhism and the culture associated with it were not receiving sufficient support or respect. The world-wide celebration of the 2500th anniversary of the death of the Buddha - the Buddha Jayanthi - was scheduled for 1956 and this afforded a marvellous opportunity to Buddhist activists for their campaigns. At the same time a report by a prestigious non-government commission (consisting of eminent Buddhist personalities), on the state of Buddhism in Sri Lanka heightened these fears - they charged that Buddhism was in a parlous state, and they laid the responsibility for this on the ruling elite ${ }^{10}$.

If religious fervour was the prime determinant of change, the language question was its sharp cutting edge. Indeed the two - Buddhism and Sinhala - were so closely intertwined that it was impossible to treat either in isolation. The anxiety to preserve and strengthen the Sinhala language stemmed partly at least from the

10 See, D. E. Smith (ed), South Asian Religion and Politics (Princeton University Press, 1966) especially pp. $453-488$. 
fear that if it fell into decay in Sri Lanka, its valuable religious and cultural tradition would die with it. What occurred at this time was a profoundly significant transformation of nationalism - language became the basis of nationalism on the model of Central Europe in the mid-nineteenth century ${ }^{11}$. This transformation of nationalism affected both the Sinhala and Tamil populations.

Up to the early 1950's the Tamils' concept of nationalism lacked coherence and cohesiveness despite all their talk of a linguistic, religious and cultural separateness from the Sinhalese. As with the Sinhalese it was language which provided the sharp cutting edge of a new national self-consciousness. This was the Federal Party's great contribution to Tamil politics. Not only did they draw attention to the possession of a viable Tamil territorial unit, and the memory of the independent Tamil kingdom which had survived from the thirteenth century to the beginning of the seventeenth, they also emphasised the role of language as the determinant of nationhood. As early as 1951 at the first national convention of the Federal Party, it was claimed that "the Tamil-speaking people in Ceylon constitute[d] a nation distinct from that of the Sinhalese by every fundamental test of nationhood." They drew attention to the "separate historical past" of the Tamils, and their linguistic unity and distinctiveness. This view has been consistently emphasised by the Federal Party as well as by other Sri Lanka Tamils in recent years, and it is the foundation of their claim for a measure of regional autonomy (ranging from a unit or units in a Federal structure, to the more recent agitation for a separate state).

One of the immediate consequences of the transformation of nationalism was that the concept of a multi-racial polity ceased to be politically viable any longer. In Sinhala the words for nation, race and people are practically synonymous and a multi-racial or multi-communal nation or state is incomprehensible to the popular mind. The emphasis on the sense of uniqueness of the Sinhalese past and the focus on Sri Lanka as the land of the Sinhalese and the country in which Buddhism stood forth in all its pristine purity, carried an emotional appeal compared with which the concept of a multi-racial polity was a meaningless abstraction.

Secondly the abandonment of the concept of a multi-racial polity was justified by laying stress on the western concept of a democratic sanction deriving its validity from the clear numerical superiority of the Sinhala speaking group. At the same time the focus continued to be an all-island one, and Sinhala nationalism was consciously or unconsciously treated as being identical with a Sri Lanka nationalism. The minorities, and in particular the indigenous Tamils refused to endorse the assumption that Sinhala nationalism was interchangeable with the larger Sri Lanka nationalism.

While Bandaranaike had ridden to office on a massive wave of Sinhala-Buddhist emotion, the sobering realities of political power compelled him to impose restraints. The race riots which broke out in the wake of the introduction of the Sinhala Only bill had underlined the combustible nature of linguistic nationalism

\footnotetext{
11 For a succint analysis of linguistic nationalism in mid-nineteenth century Europe, see Sir Lewis Namier, "Nationality and Liberty" in his Vanished Supremacies (London, 1962). See also Edmund Leach, The Political Systems of Highland Burma (London, 1954), p. 59 where he states: "For a man to speak one language rather than another is a ritual act, it is a statement about one's personal status; to speak the same language as one's neighbours expresses solidarity with those neighbours, to speak a differerent language from one's neighbours expresses social distance or even hostility." Leach makes these comments about Burma, but they would be equally true of contemporary India or Sri Lanka.
} 
in a plural society. Thus while this legislation was introduced and piloted through the legislature, its full implementation was postponed to January 1961. In August 1956 the Federal Party at a convention held in Trincomalee set out a list of demands on behalf of the Tamils. The first among these was autonomy for the Northern and Eastern Provinces under a federal constitution; parity of status for the Sinhalese and Tamil language, and a satisfactory settlement of the problem of the Indian Tamil plantation workers in the island.

In 1925-26 when Bandaranaike as leader of the Progressive Nationalist Party had set out the case for a federal political structure for Sri Lanka, and made this the main plank of the political programme of his "party", he had received no support for it from the Tamils. His ardour for federalism cooled over the years, but it was a grim irony that he should be called upon, at the moment of his greatest political triumph, to articulate the strong opposition of the Sinhalese to any attempt to establish a federal constitution. The Sinhalese viewed the Tamils' demand for a federal constitution as nothing less than the thin edge of the wedge of a separatist movement. The fact is that the Sinhalese, though an overwhelming majority of the population of the island, nevertheless have a minority complex vis-a-vis the Tamils. The Sinhalese feel encircled by the more than fifty million Tamil speaking people in present day Tamilnadu and in Sri Lanka. Within Sri Lanka the Sinhalese outnumber the Tamils by more than three to one; but they in turn are outnumbered by nearly six to one by the Tamil speaking people of South Asia.

Historical tradition, cultural distinctions and geography separate the Tamils of Sri Lanka and Tamilnadu from each other, and in the early years of independence in Sri Lanka the Tamils of the North and the East in the island had showed little inclination to identify themselves with the Tamils of Tamilnadu. Nevertheless the Sinhalese feared this possibility, and the campaign for federalism aggravated these fears. There was suspicion too of the attempt of the Federal Party to make the settlement of the problem of Indian plantation workers in the island a plank in their political platform. The only link between the two groups was language. Thus the programme of action outlined by the Federal Party in August 1956 was regarded as having ominous long-term dangers.

While the extremists in the ranks of the coalition he led could think only in terms of maintaining pressure on the Tamils in a policy of confrontation, Bandaranaike was devising schemes for a statesmanlike settlement with the Tamils. And with this in view he conducted negotiations with the Federal Party. The terms of this compromise were made public in July 1957: firstly, the Tamil language was to be an official language for administrative purposes in the Northern and Eastern provinces; secondly, as a concession to the Federal demand Bandaranaike agreed to establish a scheme of devolving administrative powers to regional councils; and thirdly he agreed to impose restraints on the settlement of Sinhalese colonists in irrigation schemes in the Northern and Eastern provinces so that the indigenous Tamils could maintain their majority position in these areas.

The moment the terms of settlement were made public there was a storm of protest chiefly from the extremists in Bandaranaike's own camp. And the UNP looking for a means of staging a comeback came out in opposition to the settlement. They were provided with an ideal opportunity to embarrass the Prime Minister on a politically sensitive issue, and to demonstrate their commitment to the Sinhala only policy to an electorate sceptical of their motives. Confronted with mounting 
opposition to this compromise the Prime Minister played for time, but the pressures against it were too strong for him to resist. Led by a group of bhikkhus ${ }^{12}$ who performed satyagraha on the lawn of the Prime Minister's private residence in Colombo, the extremists in his own party compelled him to abrogate the pact.

Once again the tensions generated by these pressures and counter pressures erupted in race riots in May 1958. To assuage the feelings of he Tamils, Bandaranaike, in August 1958 secured Parliamentary approval of the Tamil Language (Special Provisions) Act to permit the reasonable use of Tamil in administration. Though it was an important concession, it did not mollify the Tamils. In any case though the bill was approved by Parliament the regulations necessary for its implementation were not passed till 1966.

An important point about Bandaranaike's abortive settlement with the Federal Party needs to be emphasised. Despite its abrogation in 1958, it nevertheless continued to be for about ten years thereafter, the basis for negotiations for solutions to the Sinhalese-Tamil problem in the island.

One of the significant features of linguistic nationalism was increased pressure for a closer association of the state with Buddhism, and a corresponding reduction of Christian influence. These pressures often included agitation for the declaration of Buddhism as the state religion, but this Bandaranaike would not accede to. At the same time he did nothing to restrain his Minister of Education in the resistance to heavy pressure from Buddhist activists to bring all schools under state control. On the whole Bandaranaike's government was much more cautious in handling matters relating to the interests of the Christian - largely Roman Catholic minority than it was on the language issue. This caution stemmed from a realistic assessment of the political situation in the country - having embroiled itself with the Tamils on the language question there was no desire to add to its problems.

In February 1957 Bandaranaike appointed the Buddha Sāsana Commission to make recommendations for the reform of the sangha ${ }^{13}$, and for proposals regarding the general principle of "according to Buddhism its rightful place in the country", to which the government was committed. And the government raised the two premier seats of Buddhist learning, the Vidyalankara and Vidyodaya pirivenas ${ }^{14}$ to the status of Universities.

A Ministry of Cultural Affairs, and a department of Official language affairs were established, the latter to organise the implementation of the government's language policy, and the former to organise state patronage to literature and the arts. In the revivalist atmosphere of the mid-1950's there was a general efflorescence in the arts against the background of the militant Buddhist revivalist movement actuated on the one hand by the millennial expectations connected with the Buddha Jayanthi, and on the other by the nativistic urge to guard and preserve the Sinhala language and the Buddhist religion from the "threats" of the Tamils and the Christians. The year 1956, by a remarkable coincidence with the victory of the MEP, marked several momentous achievements in the arts.

Though none of these latter owed anything to the patronage of the state, the argument that the breakthrough theyr marked could be stabilised and consolidated only by active support from the state for literature and the arts became part of

12 A monk or priest, a member of the Buddhist order - the sangha.

13 The Buddhist clergy; order of bhikkhus (monks or priests).

14 Educational institutes attached to Buddhist viharas (temples). 
the conventional wisdom of the day. The institutional apparatus established for this purpose by the Bandaranaike government - a Ministry of Cultural Affairs was expected to give official patronage and financial assistance to the resuscitatory zeal then manifest in all spheres of the arts.

Linguistic nationalism ${ }^{15}$ as it emerged in the mid-1950's was a populist nationalism truculently democratic in outlook. Ideologically hazy and politically opportunistic, Bandaranaike's "middle way" promised people social change, social justice, economic independence from foreign powers and political sovereignty. More importantly it gave the common people a sense of dignity and buttressed their self-respect.

Not surprisingly one of the notable consequences of the emergence of Sinhala Buddhist populism was the setback it gave the Marxist movement which had completely underestimated the strength of linguistic nationalism. In the early months of Bandaranaike's administration, the LSSP were regarded - not least by themselves - as a viable alternative for the future. The LSSP used its position in Parliament to expose the weaknesses and contradictions within Bandaranaike's coalition especially when the government was enmeshed in the politics of the language problem with Bandaranaike seeking at once to placate the Federal Party, which was resorting to extra-parliamentary forms of struggle, and to appease the forces of Sinhalese extremism within and outside the ranks of his coalition. The LSSP which advocated - at that time - the recognition of both Sinhalese and Tamil as official languages, were critical of the dangerously divisive effects of Bandaranaike's language policies. But the Sinhalese masses were totally unresponsive to these criticisms. At the same time the LSSP used its trade union strength to launch a series of massive strikes through the years 1956 to 1959. Many of these strikes were politically inspired, and aimed at embarrassing the government. In so doing they were exploiting the wide tolerance which the trade union movement enjoyed after 1956. But the effect of this irresponsible resort to trade union action for frivolous reasons was to discredit the LSSP in the country at large.

They had always aspired to the status of the alternative government, and it was this aspiration which was thwarted by the emergence of linguistic nationalism and the populist form it took in the mid-1950's. They watched the gains of the past disappear, and the prospects of the future become much more limited. They found to their dismay, and discomfiture, that linguistic nationalism had an appeal which cut across class interests, and that it evoked as deep a response from the Sinhala working class as it did among the peasantry and the Sinhala educated elite. The cosmopolitan outlook of the Marxists and their enlightened advocacy of a multi-racial secular polity proved to be profoundly disadvantageous, and they were compelled to compromise on these issues without, however, any substantial political benefits. From the position of the alternative government they were reduced - after 1960 - to the status of an appendage of the populist Sri Lanka Freedom Party.

Though the Buddhist movement was generally hostile to Marxist ideology, it had no strong opposition to the adoption of a socialist programme. Since plantation enterprise, nascent industry and the island's trade were dominated by foreign

15 This linguistic nationalism, despite its seeming novelty at the time it first appeared in the mid-1950's, had its roots in the recent past, especially in the temperance movement of the early years of the twentieth century when a similar mixture of religious fervour and commitment to national culture
had captured the imagination of the people particularly in the rural areas of the low country. In the nineteen fifties the scale was wider and the appeal deeper. 
capitalists, and the minorities were disproportionately influential within the indigenous capitalist class, Buddhist pressure groups viewed socialism as a means of redressing the balance in favour of the majority group. Every extension of state control over trade and industry, could be justified on the ground that it helped curtail the influence of foreigners and the minorities. The Sinhala Buddhist section of the capitalist class was not averse to socialism so long as its own economic interests were not affected. The result was that the populist Sri Lanka Freedom Party has been able to reconcile a commitment to socialism with an advocacy of the interests of a section of the indigenous capitalist class - the Sinhala Buddhist segment of it.

Bandaranaike's mastery of Parliament was more effective than his control of the Cabinet and the coalition he led. Pressures and counter-pressures were pulling his Cabinet apart within a short time of his victory in 1956, and it needed all his resources of prestige and influence to keep it together as an effective instrument of social reform. It was evident that his sympathies were with the left-wing members of his Cabinet, three of whom did not belong to the SLFP. He respected their intellectual ability, their administrative skills, their sense of priorities and purposeful approach, and above all their integrity. But they were a minority, and the Prime Minister came increasingly under pressure from the majority - who belonged to his party - to impose restraints on the innovative and reformist minority. By the beginning of 1959 the coalition was coming apart, though in Parliament the SLFP was strong enough, thanks to the disarray in the ranks of the opposition, to continue its dominance. The first phase of the political crisis ended with the resignation of the left-wing group in the Cabinet, but the Prime Minister was now left with a Cabinet of mediocrities, and a party in which the more liberal and reformist groups were becoming less influential.

It is important to remember that Bandaranaike's assassination in September 1959 was the culmination of a bitter struggle for power within his own party. The instrument of his assassination was a bhikkhu and the chief conspirator was the most powerful political bhikkhu' ${ }^{16}$ of the day who had contributed greatly to Bandaranaike's triumph in 1956. In this conspiracy to murder Bandaranaike the most sordid commercial considerations were mixed with the zest for control over the government.

At the time of his assassination Bandaranaike was no longer the masterful polician he had been in 1956-57, and his hold on the electorate was not as strong as it was then. But his murder dramatically changed the political situation, and after a few months of drift and re-grouping, the SLFP emerged under the leadership of his widow more powerful than ever before. Death is the essence of mythmaking, and they had before them the inestimable advantage of the Bandaranaike myth with which to face the electorate, and to fashion the discomfiture of their rivals on the political scene. 16 On the role of the political bhikkhus in the politics of this period see Wriggins, op. cit. passim; D. E.
Smith (ed), South Asian Religion and Politics, especially pp. $489-510$. 